\title{
Trabalho e gênero nas indústrias automotivas do Sul Fluminense
}

\author{
Letícia F. Paes' \\ Ana Paula Vasconcelos Gonçalves ${ }^{2}$ \\ Vitor Rodrigues Ferreira ${ }^{3}$
}

\section{Resumo}

O presente trabalho tem como objetivo identificar as desigualdades de gênero nas fábricas automotivas do Sul Fluminense - Rio de Janeiro, através da análise exploratória dos dados da Relação Anual das Informações Sociais (RAIS), do Ministério do Trabalho e Emprego (MTE). Desde 1996, com a chegada da Volkswagen ao município de Resende, o governo do estado passou a implementar medidas visando à atração de outras indústrias, em especial montadoras de veículos. Ao longo dos anos seguintes, os municípios localizados no Sul Fluminense se converteram em um novo polo automotivo, ocupado por uma diversidade de empresas que dinamizaram a economia local e geraram um grande volume de empregos. Com dados compreendidos entre os anos de 2007 e 2017, o trabalho buscou verificar de que maneira esse desenvolvimento se deu no tocante às disparidades retratadas na literatura sobre gênero e trabalho na indústria brasileira.

Palavras-chave: Gênero. Desigualdade. Trabalho. Sul Fluminense.

\section{Introdução}

A industrialização brasileira tem a concentraçáo espacial como uma de suas principais características. No caso da indústria automobilística, as primeiras plantas foram instaladas em São Paulo na década de 1920. Posteriormente, outras fábricas também foram implantadas na cidade e no seu

I Atualmente, cursa mestrado no Programa de Pós-Graduação em Sociologia, da Universidade Federal Fluminense (UFF). E-mail: leticiapaes@id.uff.br

2 Doutora em Sociologia pelo Instituto de Estudos Sociais e Políticos, da Universidade Estadual do Rio de Janeiro (UERJ). E-mail: anapaulavasconcelos@gmail.com.

3 Atualmente, cursa mestrado no Programa de Pós-Graduação em Sociologia e Antropologia, da Universidade Federal do Rio de Janeiro (UFRJ). E-mail: vitorff@gmail.com

\section{$(\mathrm{cc}) \mathrm{Br}$}

Direito autoral e licença de uso: Este artigo está licenciado sob uma Licença Creative Commons. Com essa licença você pode compartilhar, adaptar, para qualquer fim, desde que atribua a autoria da obra, forneça um link para a licença, e indicar se foram feitas alterações. 
entorno, formando o conhecido ABC paulista. A partir da década de 1950, foram instituídas políticas públicas direcionadas ao desenvolvimento do setor automobilístico: o mercado doméstico foi fechado, criando medidas de proteção contra os veículos importados, e um processo de fomento às fábricas locais foi instaurado a fim de alcançar um complexo industrial integrado, visando à nacionalizaçáo da produção dos automóveis. Outras medidas também foram tomadas, como subsídios e a proteção às empresas estrangeiras do setor que se instalassem no país, bem como a oferta de infraestrutura, de mão de obra barata e de um mercado interno em expansão, com base, principalmente, no intenso investimento estatal no transporte rodoviário. Dessa forma, foram atraídas, no contexto do plano de metas do governo Juscelino Kubitscheck, outras empresas multinacionais. Algumas delas se associaram inicialmente ao capital nacional, como foi o caso da Volkswagen com o grupo Monteiro Aranha (BOTELHO, 2002).

Até 1990 a indústria automobilística ainda usufruía dos benefícios provenientes das antigas políticas desenvolvimentistas implementadas nas décadas de 1950 e 1960 . Entretanto, durante a década de 1990, a economia brasileira passou por um processo de abertura e de reestruturação, o qual afetou este setor de forma direta. Após a estabilidade macroeconômica advinda do Plano Real, foi criado o Regime Automotivo Brasileiro ${ }^{4}$ com o intuito de revitalizar a indústria automobilística e atrair novas fábricas de veículos e autopeças. Dentre as medidas executadas, estava a redução da alíquota de importação de máquinas, matérias-primas e equipamentos, a redução do índice de nacionalização dos veículos, o aumento dos incentivos à exportação, e tarifas de importação preferenciais sobre automóveis importados por empresas instaladas no país.

Segundo Posthuma (2000), essas políticas incentivaram a aquisição de equipamentos e matéria-prima do exterior e viabilizaram a modernizaçáo das fábricas existentes. As medidas contribuíram também para que a indústria automobilística brasileira pudesse se especializar na produção de modelos de tamanhos médios, adequados ao mercado.

É importante destacar que a revitalização da indústria automobilística no Brasil traz consigo uma nova distribuição geográfica das fábricas do setor.

4 O Regime Automotivo Brasileiro foi aprovado em junho 1995 com o propósito de modernizar o parque industrial, acelerar o investimento e ampliar a competitividade externa do segmento automobilístico. 
Esse processo se deu em um contexto de reestruturação espacial da indústria nacional, no qual empresas deslocaram os investimentos antes muito focados em polos industriais tradicionais, como é o caso do ABC Paulista, para regiôes mais afastadas dos grandes centros (RAMALHO, 2005). Essa nova lógica espacial ocorreu devido aos incentivos fiscais que os municípios e estados passaram a conceder às empresas para se instalar em seus territórios, à existência de máo de obra qualificada, excedente e mais barata fora dos grandes centros urbanos, e à presença de um sindicato mais fraco do que aquele existente nas grandes metrópoles, o que facilitou acordos coletivos mais vantajosos para as indústrias.

O estado do Rio de Janeiro se beneficiou com esta nova configuração geográfica das indústrias, pois várias montadoras começaram a se instalar em seus municípios, sobretudo na região do Sul Fluminense. É nesse período que a implantação da Volkswagen em Resende, bem como a da francesa PSA-Peugeot Citröen na cidade vizinha (Porto Real) em 2001, marcaram o que pode ser considerado o princípio do polo automotivo do Sul Fluminense, que figura atualmente entre os grandes centros industriais do país.

Com localização privilegiada, entre os eixos RJ-SP, o Vale do Paraíba Fluminense, abrange nove municípios: Barra Mansa, Itatiaia, Pinheiral, Piraí, Porto Real, Quatis, Resende, Rio Claro e Volta Redonda. A região, que na década de 1930 vivia a decadência do ciclo do café, entrou em um processo de industrialização progressiva, desde uma reestruturação e modernizaçáo de sua infraestrutura entre 1940 e 1970 com a inauguração da Rodovia Presidente Dutra, a construção da Academia Militar das Agulhas Negras e da Companhia Siderúrgica Nacional, e a entrada em operação da Usina Hidrelétrica do Funil, chegando ao estabelecimento do Polo-Urbo-Industrial de Porto Real nos anos 1990 e o polo metal-mecânico nos anos 2000 (LIMA, 2005).

Em 2013, os municípios de Porto Real, Itatiaia, Resende e Quatis assinaram o protocolo de criação do Consórcio Intermunicipal de Criação de Emprego e Renda, visando uma maior colaboração entre si. O consórcio ficou conhecido como PRIQ, e delimita os municípios sul fluminenses que abrigam o polo automotivo (RESENDE, 2013). Além de Volkswagen e Peugeot-Citröen, atualmente, o polo é composto por outras três grandes montadoras de veículos: a Hyundai Heavy-Industries e a Jaguar Land Rover em Itatiaia, e a Nissan Motor Co. Ltda. em Resende (LIMA, 2020). 
Diante dessa mudança na configuração industrial da região, o Sul Fluminense vem se tornando objeto frequente de estudos sobre os impactos e arranjos que o setor automotivo constitui nas relaçóes entre trabalhadores, empresas, sindicatos, comunidade e setor público.

Diante da importância das indústrias automotivas na geração de emprego e renda para a regiáo, este trabalho tem como objetivo identificar as desigualdades de gênero nas fábricas automotivas do Sul Fluminense. Sob a perspectiva da literatura de gênero e trabalho, o que se pretende é formar um panorama inicial do perfil das trabalhadoras do setor automotivo na área de estudo, verificando se há fatores indicativos de diferenças persistentes e/ou sistemáticas entre homens e mulheres, essencialmente nas contratações, funções e salários, a exemplo de pesquisas (LAPA, 2018; LOBO, 1991; RIZEK; LEITE, 1998) sobre a discriminação das trabalhadoras do setor em outras regióes. Espera-se que os resultados aqui apresentados possam fomentar futuros estudos sobre o tema, especialmente na região Sul Fluminense.

\section{Trabalho e Gênero}

Temáticas voltadas para gênero, raça e classe compóem parte da preocupação da literatura das ciências sociais sobre o mundo do trabalho no que tange questóes sobre desigualdade, exploração e precarização. Se, de um lado, a globalizaçáo e a internacionalização de grandes fábricas trouxeram desenvolvimento econômico e mudanças tecnológicas que melhoraram as condiçóes de trabalho, por outro, a assimetria entre grupos de trabalhadores mantém-se no cerne da organização neoliberal, como é o caso da divisão por gênero (HIRATA, 2015).

Hirata e Kergoat (2007), em revisão crítica ao emprego do termo divisão sexual do trabalho, atribuíram dois caminhos frequentemente seguidos em pesquisas sobre o tema: uma visão mais sociográfica, que demonstra a distribuição assimétrica de cargos e ofícios e como essa ocupação díspar se relaciona com a distribuição de trabalho doméstico por sexo; e uma segunda visão, mais sistemática, que busca associar a distribuição desigual no mercado de trabalho com uma hierarquização das atividades que venha a criar um sistema de gênero.

As autoras definem essa divisão sexual do trabalho não apenas como resultante da diferença numérica entre os gêneros, como também um fato 
estruturante da relação hierárquica entre homens e mulheres, reforçada histórica e socialmente. Essa noção sistemática enxerga a divisão como atribuidora do papel produtivo aos homens e reprodutivo às mulheres, que empenhariam uma considerável quantidade de trabalho (como cuidar da casa e dos filhos) de forma gratuita, praticamente invisível e naturalizada. Nesse sentido, o que as autoras enfatizam é a impossibilidade de se dissociar as relações intrínsecas entre trabalho/família/sociedade, que formariam um "ciclo vicioso" numa divisão sexual não apenas do trabalho, mas também do saber e do poder.

Essa divisão seria norteada, então, por dois princípios, aos quais $\mathrm{Hi}$ rata e Kergoat (2007, p. 599-600) denominam como princípio da separação e princípio hierárquico. O primeiro estaria relacionado à distinção por trabalhos que seriam exclusivos a homens ou a mulheres, segmentando os gêneros já em suas funçóes. $\mathrm{O}$ segundo princípio estaria relacionado aos trabalhos em que o gênero serve como parâmetro de valor, de modo que um "trabalho masculino" teria mais valor. Diante dessa cisão, aos homens caberiam funçóes mais valorativas socialmente - como cargos de liderança na esfera política, militar ou religiosa, por exemplo. Esses princípios por divisão de gênero seriam centrais na organização do trabalho na globalização neoliberal, mantendo a distância entre os sexos, ainda que com mudanças ou avanços, de maneira que "tudo muda, mas nada muda" (HIRATA; KERGOAT, 2007, p. 6).

Hirata (2015) chama a atenção, por exemplo, para a questão da escolaridade, segundo a qual, apesar de possuírem um grau de instrução e diplomação mais elevado que os homens em praticamente todos os países e em todas as faixas etárias, as mulheres mantém-se como minorias em cargos executivos ou de níveis superiores (médicas, engenheiras, juízas, pesquisadoras etc.). Em análise comparativa entre França, Brasil e Japão, a autora constatou que as mulheres ainda constituem maioria em cargos e funçóes com menos prestígio social e menor remuneração (empregadas domésticas, secretárias, caixas, vendedoras etc.). Esses dados indicam um avanço na escolarização que não é acompanhado de uma mudança sistemática de fato. No caso do Brasil e França, a autora relata que as mulheres continuam a encarar mais dificuldade na formaçáo profissional com o acúmulo de trabalho doméstico e assalariado e, ainda, na promoção ou contrataçáo para cargos de liderança e maior remuneração. 
Trata-se do fenômeno denominado teto de vidro, "[...] uma barreira que, de tão sutil, é transparente, mas suficiente para impossibilitar a ascensão de mulheres a níveis mais altos da hierarquia organizacional" (STEIL, 1997, p. 62). Isso indica um limite imposto de forma sistemática em que os avanços das mulheres no aumento de escolaridade e inserção no mercado de trabalho são observáveis até certo ponto, esbarrando em questôes como a ausência significativa de mulheres em cargos de chefia ou a diferença de salários entre homens e mulheres em uma mesma função. De acordo com Hinings e Greenwood (apud STEIL, 1997), este fenômeno estaria atrelado a um processo de manutenção de suas posiçóes de poder dentro de organizaçôes. Uma vez que cargos de destaque já são ocupados por homens, estes terminariam, por vezes, a inferir um tratamento desigual a mulheres não apenas no momento da contratação, como no desenvolvimento de dinâmicas de aprimoramento, avaliação de desempenho, delegação de projetos etc., de modo a abarcar toda a estrutura organizacional e garantindo a perpetuação do status quo. Hirata (2015) comenta, por exemplo, sobre as técnicas e engenheiras em empresas multinacionais que enfrentavam resistência de empregados homens subordinados, fato que fez muitas dessas mulheres perderem seus cargos. Em outras palavras, uma vez que homens constituem grupos de poder dentro das organizaçóes, esses definiriam quais espaços seriam passíveis de serem ocupados por profissionais do gênero feminino (STEIL, 1997), resultando na desigualdade entre homens e mulheres nos postos mais altos.

Essa hierarquização leva a outro dado: as mulheres têm, internacionalmente, salários menores que dos homens, o que nacionalmente está em uma diferença em torno dos 30\% (HIRATA, 2015). A hierarquização e segmentação seguem por outros grupos, que a autora define como sendo: os homens brancos detentores dos maiores salários, seguidos dos homens negros e mulheres brancas, e, com uma diferença bem mais significativa, as mulheres negras. É nesse sentido que Hirata (2015) determina o gênero enquanto fator-chave que perpassa as dinâmicas desiguais da organização neoliberal.

A desigualdade de gênero vista no mercado de trabalho prejudica as mulheres de diferentes modos. Por um lado, elas possuem dificuldades de ocupar postos de trabalho com maior prestígio e salários maiores, 
limitando suas possibilidades de mobilidade social. Por outro, mesmo quando comparadas a homens, com quem compartilham o mesmo cargo, as mulheres tendem a receber menos. Xavier, Tomás e Candian (2009), ao analisar os dados da PNAD 2003, afirma que as mulheres elevam menos seus salários somente pelo fato de serem mulheres, assim como descrito por Hoffmann (2020), ao analisar os salários médios de homens e mulheres de 1992 até 2019. Segundo o autor, as mulheres, mesmo com escolaridade mais elevada, possuem salários médios mais baixos que os homens. Já Silveira e Leão (2017) buscaram verificar as diferenças salariais por gênero e raça a partir dos dados da PNAD de 1996 e 2004, e concluíram que a expansão do mercado de trabalho brasileiro apresenta tendências à igualdade. Contudo, ainda há um longo caminho a ser percorrido; afinal, as mulheres ainda apresentam desvantagens salariais em relação aos homens, principalmente as mulheres negras.

De acordo com Teixeira (2008), enquanto se formavam os primeiros debates em defesa da igualdade salarial, período compreendido entre o final do século XIX e início do século XX, o argumento então mobilizado para justificar a superioridade salarial masculina era a ideia de "salário familiar". Trata-se da noção de que homens deveriam receber salários superiores às mulheres, uma vez que seriam encarregados de sustentar e gerir a família. Às mulheres assalariadas, por outro lado, caberia receber somente o básico para a própria subsistência, o que legitimaria seu padrão de remuneração mais baixo. Com a participação da mulher no mercado de trabalho e as transformaçóes na estrutura familiar durante as décadas seguintes, novas justificativas para a desigualdade salarial passam a ser mobilizadas. Rachel Silveira (2003 apud LAPA, 2016) comenta sobre alguns desses estereótipos que legitimam a desigualdade salarial entre os gêneros, dentre eles, a presunção de que mulheres não conseguem se dedicar tanto ao trabalho quanto homens, por precisarem conciliá-lo às tarefas domésticas.

No caso da indústria automotiva, a diferença entre gêneros se expressa essencialmente através do número de contrataçóes e dos salários pagos de forma díspar entre homens e mulheres. Segundo Lobo (1991), entre 1970 e 1975, a proporção de trabalhadores no setor automobilístico era uma mulher contratada para cada 13 homens. Atualmente a falta de igualdade no setor permanece. Uma pesquisa realizada pela Automotive Business 
(2018), apontou que a participaçáo feminina em 2017 era de 17\%; dentre estas trabalhadoras, $46 \%$ estavam alocadas na produção e manufatura. A diferença salarial entre os estagiários era menor, pois as mulheres tendem a ganhar somente 0,8\% menos que seus colegas homens. Quanto mais as posições vão se elevando na hierarquia das fábricas as diferenças também vão se acentuando, por exemplo, as mulheres que ocupam cargos de chefia tendem a ganhar em média 33\% menos que os homens (AUTOMOTIVEBUSINESS, 2018, p. 16-19).

Outro aspecto que merece destaque é que a linha de montagem ainda é associada a uma atividade masculina. Rizek e Leite (1998) discutem essa separação ao analisar as diferenças de gênero nas ocupações dentro de quatro fábricas distintas. As autoras afirmam que as funçôes desempenhadas pelas mulheres ainda estão atreladas a habilidades como destreza, paciência e minúcia, características que se opóe à linha de montagem. Lapa (2018) reforça esse argumento em sua pesquisa de campo com metalúrgicas que trabalham em fábricas automotivas no $\mathrm{ABC}$ Paulista, onde entrevistou mulheres que sofreram preconceito e, em alguns casos, assédio ao ocuparem certas funçóes e lugares vistos como espaços masculinos. Além disso, as poucas funcionárias que ascenderam na carreira alcançando postos na produção ou técnicos, com a crise no setor, foram "rebaixadas" através de transferência de setor ou direcionamento ao lay off por serem mulheres.

\section{3 Área de Estudo}

Os municípios que compóem o polo automotivo do Sul Fluminense são Resende, Itatiaia e Porto Real. No entanto, cidades vizinhas sofrem grande influência desta atividade econômica e, por isso, também foram incluídas na abrangência da pesquisa. Como Quatis é cidade vizinha de Porto Real, foi incluída no estudo. Já Volta Redonda e Barra Mansa, segundo a pesquisa sobre as regióes de influência das cidades, realizada pelo IBGE (2007), são um conglomerado identificado como Centro Regional $\mathrm{C}$, sendo influenciadas diretamente somente pela metrópole nacional -

5 As informações de contexto sobre os municípios da área de pesquisa mais recentes são de 2010, pois a única pesquisa mais abrangente que retrata os municípios brasileiros é o Censo Demográfico, realizado pelo IBGE a cada dez anos. 
Rio de Janeiro e exercendo influência direta e indiretamente em todas as cidades do Polo Automotivo do Sul Fluminense. Isso ocorre porque ambas as cidades apresentam significativa importância para a região, por terem equipamentos e serviços que não são encontrados nos outros municípios. Inclusive, muitos trabalhadores das fábricas automotivas residem em Barra Mansa e Volta Redonda. Nessas cidades, há oferta de transporte, logística, cursos técnicos e universitários que favorecem as fábricas da região.

A Figura 1 ilustra a área de estudo, composta por Itatiaia, Resende, Porto Real, Quatis, Volta Redonda e Barra Mansa. A população destes municípios, em 2010, era de 623.553 habitantes (IBGE, 2011). Volta Redonda, Barra Mansa e Resende são os municípios mais populosos da região com: 257.803, 177.813 e 119.769 habitantes, respectivamente. Já Quatis e Porto Real possuem menos moradores em seu território. (IBGE, 2011).

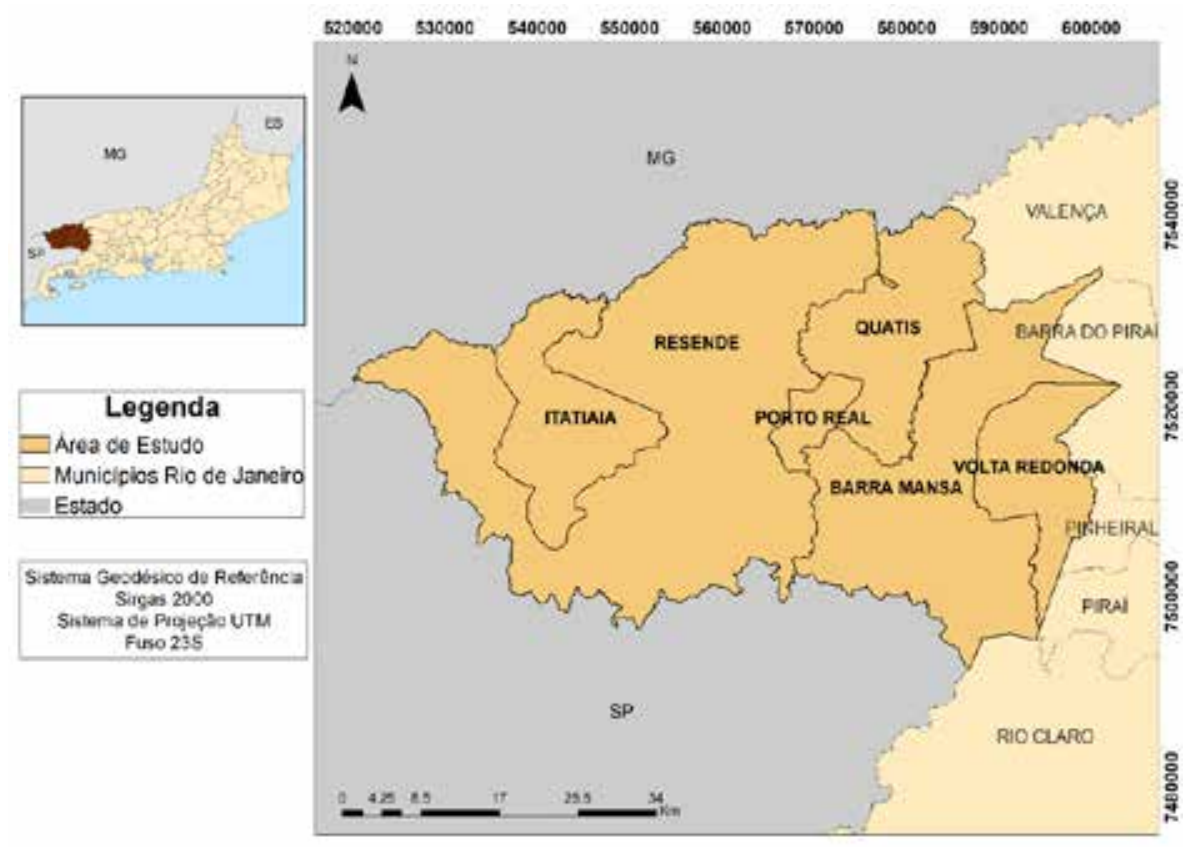

Figura I - Área de Estudo

Fonte: IBCE (20II). 
A população residente nas cidades que constituem o polo automotivo do Sul Fluminense possui mais homens até os 14 anos, conforme ilustra o Gráfico 1. Entre 19 até 24 anos há uma quantidade bem próxima entre os gêneros; mas, após 25 anos, as mulheres são maioria em todas as faixas de idade.

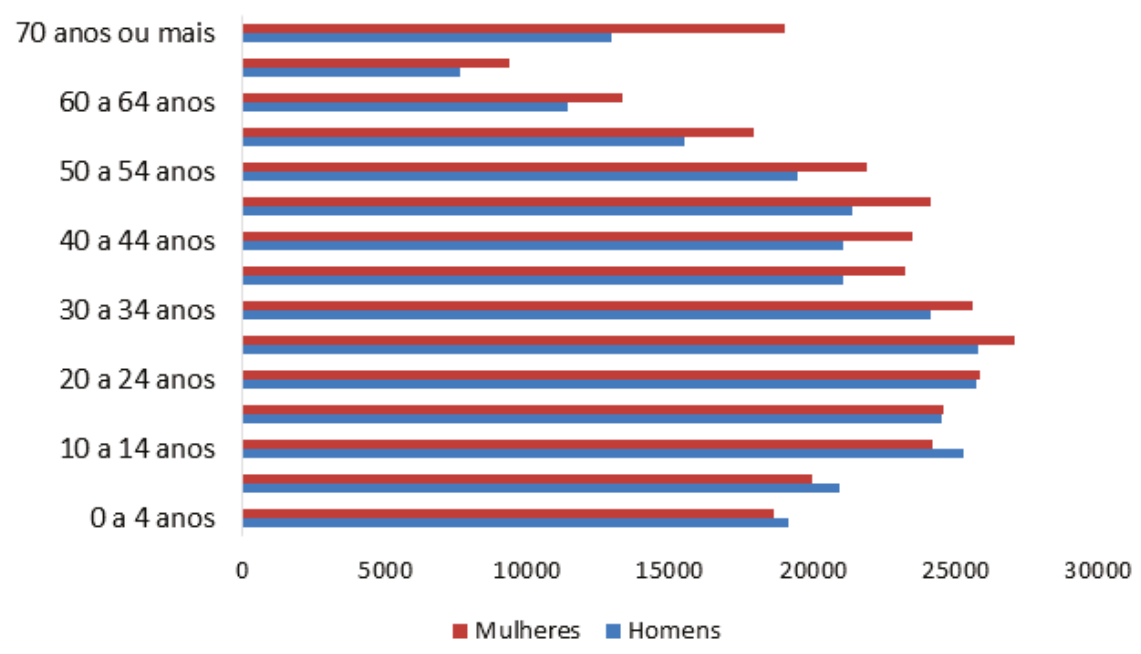

\section{Gráfico I - População do Polo Automotivo do Sul Fluminense por gênero} Fonte: IBGE (2011).

Com o intuito de observar a quantidade de homens e mulheres disponíveis para o mercado de trabalho, a Tabela 1 descreve a porcentagem dos indivíduos nas cidades estudadas que fazem parte da População Economicamente Ativa (PEA) ${ }^{6}$ por gênero. Nota-se que todos os municípios possuem em torno de $80 \%$ de sua população classificada como PEA. Com a exceção de Porto Real, em que a proporção da PEA é muito próxima entre ambos os sexos, há proporcionalmente mais mulheres que homens; ou seja, da populaçáo total, há maior porcentagem de mulheres que

6 A população economicamente ativa (PEA) são aquelas pessoas que estão em condições de trabalhar entre 10 até 65 anos. 
podem estar no mercado de trabalho. Isso indica que, em qualquer setor da economia, pode ter uma proporção de empregados similares por gênero.

Tabela I - \% da população que faz parte da PEA por gênero

\begin{tabular}{lccc}
\hline Município & Total & Mulheres & Homens \\
\hline Barra Mansa & 79,74 & 41,2 & 38,54 \\
\hline Itatiaia & 79,24 & 40,03 & 39,21 \\
\hline Porto Real & 79,47 & 39,94 & 39,53 \\
\hline Quatis & 78,72 & 39,79 & 38,93 \\
\hline Resende & 79,64 & 40,69 & 38,95 \\
\hline Volta Redonda & 80,21 & 41,87 & 38,34 \\
\hline
\end{tabular}

Fonte: IBGE (2011).

No geral, a proporçóes de homens e mulheres que compóem a população economicamente ativa da região são próximas. Esse dado invalida o possível argumento de que mulheres seriam menos contratadas pelo setor automotivo por uma possível menor oferta de mão de obra feminina disponível. Desse modo, outros fatores, como escolaridade, escolha individual de uma profissão e seleçáo interna das empresas precisam ser mobilizados para justificar eventuais índices desiguais de contratação do setor.

\section{Materiais e Métodos}

Com o intuito de identificar as possíveis desigualdades de gênero no polo automotivo do Sul Fluminense, foram utilizadas informaçóes da Relação Anual das Informaçôes Sociais (RAIS) ${ }^{7}$. Este banco de dados é um registro administrativo com periodicidade anual, obrigatório para todos os estabelecimentos, inclusive aqueles sem ocorrência de vínculos empregatícios no exercício, tendo esse tipo de declaração a denominação de RAIS Negativa.

O recorte temporal deste trabalho foi 2017 e 2007, estabelecido com intuito de verificar se ocorreram mudanças ao longo do tempo no que

7 Banco de dados do Ministério do Trabalho e Emprego, disponível pelo Programa de Disseminação das Estatísticas do Trabalho mediante solicitação de cadastro em: http://pdet.mte.gov.br/microdados-rais-e-caged. 
tange à contratação de empregados no setor automotivo por gênero. Para abarcar todas as montadoras e empresas fornecedoras que estão fixadas nesta região, foram selecionados somente os estabelecimentos que estão classificados na CNAE 95 como "Fabricação de veículos automotores, reboques e carrocerias”. A partir deste recorte inicial realizado, as variáveis selecionadas para compor a análise exploratória foram:

- Vínculos (Vínculos).

- Sexo (Sexo do trabalhador).

- Ocupação (CBO ocupação 2002).

- Escolaridade (Escolaridade agregada após 2005).

- Renda (Remuneração média nominal).

- Renda (Remuneração média em Salários Mínimos).

- Tempo no Emprego (Em meses).

Na variável renda (Remuneração média nominal), para o ano de 2007, foi necessário realizar uma correção de seus valores levando em consideração a inflação do período de análise, tornando a comparação entre 2007 e 2017 adequada. Para isso, foi usado o Índice Nacional de Preços ao Consumidor Amplo (IPCA) do mês de dezembro, tendo em vista que este é o mês de referência da RAIS.

Vale ressaltar que a análise exploratória dos dados visa a resumir e organizar as informaçôes através de tabelas, gráficos ou medidas numéricas. Seu principal objetivo é entender melhor o conjunto de dados para responder as questóes estudadas; neste caso, a assimetria de gênero nas fábricas automotivas que estão localizadas em Resende, Porto Real e Itatiaia.

\section{Discussão dos Resultados}

No setor automotivo, entre 2007 até 2017, a participação feminina não ultrapassou $20 \%$ dos trabalhadores, conforme descrito no Gráfico 2: 


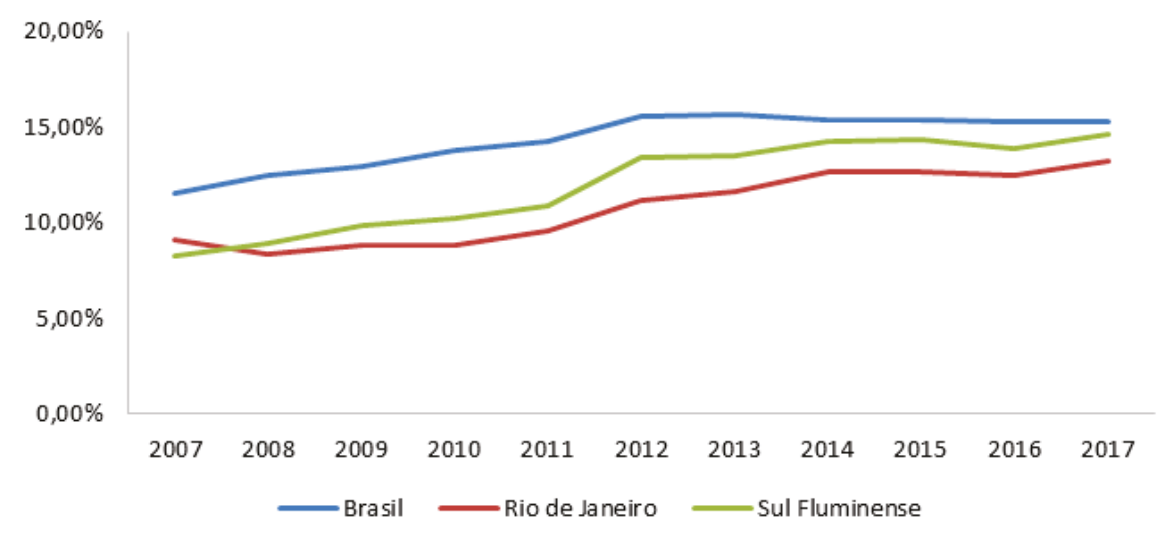

Gráfico 2 - Porcentagem da participação das mulheres no setor automotivo Fonte: RAIS (2017).

No entanto, até 2012 havia um leve incremento anual que posteriormente se estabilizou. $\mathrm{O}$ estado do Rio de Janeiro apresentou a mesma tendência do Brasil. Já no Sul Fluminense o incremento das mulheres no mercado de trabalho foi mais intenso e, após 2012, o ritmo de crescimento apenas diminuiu, mas não se estabilizou. Uma possível explicação para a redução da participaçáo feminina pode vir da crise que o setor enfrentou em 2013, na qual houve uma redução do quadro de funcionários, mesmo com medidas como o Programa de Proteção ao Emprego (PPE), como descrito por Reis (2018), no caso da "MAN Latin América", e no "Fórum Demissão Zero” citado por Ramalho (2015).

Cabe destacar que a crise econômica de 2008 não afetou de imediato o setor automotivo nacional; porém, em 2013 seus efeitos foram sentidos tanto no Sul Fluminense quanto em todo Brasil. Houve também o enfraquecimento nas vendas dos veículos automotivos, 2015. Em virtude dessas dificuldades enfrentadas pelo setor, no Sul Fluminense, ocorrerem diversas mobilizaçóes, de distintas entidades, para minimizar as demissóes dos trabalhadores (RAMALHO, 2015; DULCI, 2018; REIS, 2018).

Nesse sentido, a disparidade de gênero no período pesquisado não foi linear, em virtude das crises econômicas que afetaram o cenário de contrataçóes 
e demissóes das empresas automotivas. Contudo, a porcentagem de mulheres no setor, nacionalmente, não se estabilizou completamente porque

[...] houve redução mais significativa do quadro masculino de funcionários principalmente nas empresas de autopeças, onde a baixa chegou a $23,4 \%$. Enquanto isso, a presença feminina diminuiu apenas 10,4\% nas companhias que produzem componentes e aumentou $6 \%$ nas montadoras de veículos. (AUTOMOTIVEBUSINESS, 2018. p. 8).

Nota-se que a maioria dos trabalhadores do Polo Automotivo do Sul Fluminense é composta por homens, os Gráficos 3 e 4 mostram como se dá a distribuição dos vínculos por gênero, controlando por escolaridade e ocupação em 2007. Para esses gráficos foram utilizados os níveis de instrução ensino médio e ensino superior, pois, em geral, são os que concentram a maior parte da quantidade de vínculos.

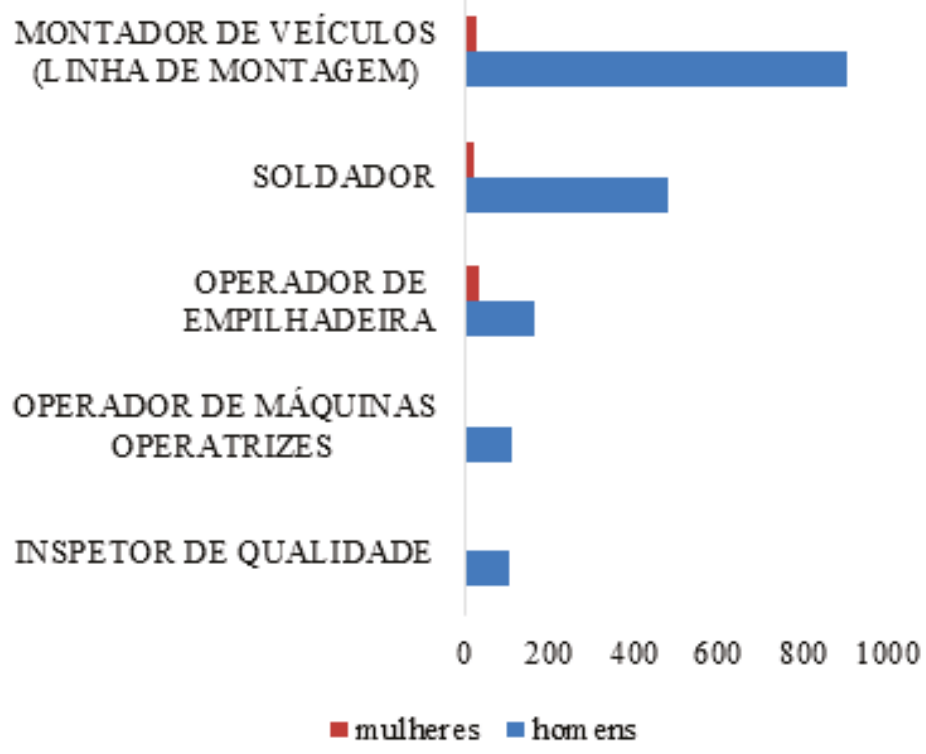

Gráfico 3 - Cinco profissões com maior quantidade de vínculos com ensino médio em 2007

Fonte: Elaborado pelos autores (2021). 


\section{GERENTE DE PRODUÇÃO E OPERAÇÕES}

\author{
AUDITOR (CONTADORES \\ E AFINS)
}

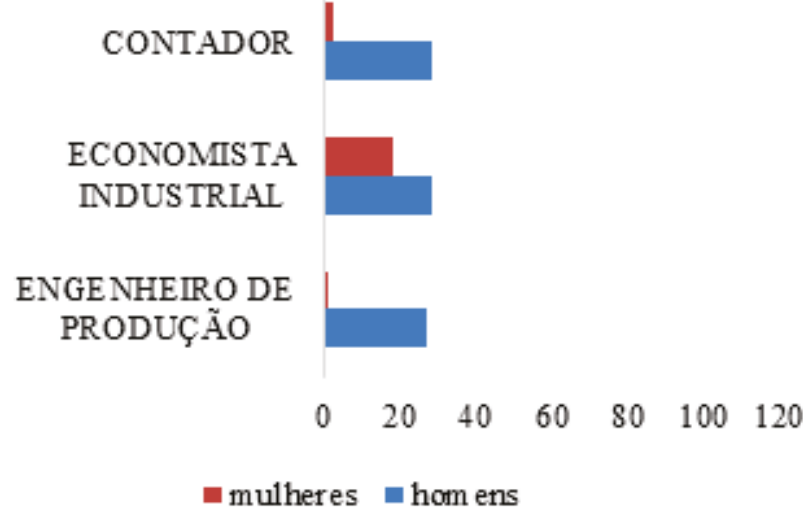

\section{Gráfico 4 - Cinco profissões com maior quantidade de vínculos com ensino superior em 2007}

Fonte: Elaborado pelos autores (2021).

Em 2007, as cinco profissóes que empregaram maior número de trabalhadores com ensino médio estão associadas à linha de produção, como se observa no Gráfico 3. As mulheres são minoria nas cinco ocupaçóes, possivelmente pelo trabalho na linha de montagem ainda estar associado a uma atividade masculina, pois os trabalhos nesses setores das fábricas ainda são vistos como mais pesados e difíceis de serem executados quando não se detém força física, atributo ainda visto como masculino (RIZEK; LEITE, 1998; HIRATA, 2015).

A ocupação "montador de veículos (linha de montagem)", em 2007, apresentava a maior quantidade de vínculos: 900 homens e 30 mulheres, o que representa $96,7 \%$ e 3,3\% respectivamente. Nesse ano havia mais mulheres contratadas como "operadores de empilhadeira", pois eram $33 \mathrm{em}$ 
número absoluto, representando $16,5 \%$ dos contratados nesta ocupação. Mesmo assim a diferença ainda era alta, porque os homens somavam 167 na ocupação em questão, ou seja, 83,5\%.

Em relação às ocupaçóes com nível superior em 2007, nota-se, no Gráfico 4, que a diferença entre homens e mulheres que ocupavam o cargo de "gerente de produção e operaçôes" não era tão acentuada quanto o cargo de "montador de veículos", profissão com maior quantidade de vínculos com ensino médio: 135 (79,4\%) homens e 35 (20,6\%) mulheres. A profissão de "economista industrial" também apresenta valores mais próximos, com 18 (39,1\%) mulheres empregadas e 28 (60,9\%) homens. Assim, fica perceptível que, dentre os indivíduos com maior escolaridade, a diferença entre homens e mulheres é notória, mas tende a ser menor do que entre as profissóes que requerem o ensino médio. A diferença salarial menor nas ocupaçóes que requerem um nível de escolaridade mais baixo também foi notada por Leone e Baltar (2012) ao fazerem um balanço sobre a desigualdade de gênero no mercado de trabalho brasileiro, a partir dos dados da PNAD de 2009 e da RAIS de 2010.

Este fato pode ter relação com o tipo de trabalho realizado nestas ocupaçóes, visto que, dentre as cinco profissóes com mais trabalhadores com ensino superior, "economista industrial", "contador" e "auditor" são consideradas profissões administrativas, não diretamente ligadas ao chão de fábrica. Dois pontos são interessantes acerca dessa distribuição de cargos e funçôes. O primeiro diz respeito ao contraste com funçóes da linha de montagem que são tidos como mais "masculinos", no espectro da segmentaçáo, seguindo o que apresentam Rizek e Leite (1998), enquanto os cargos do Gráfico 4 estão mais ligados a atividades de escritório e mais passíveis de serem ocupados por mulheres, sendo esses espaços considerados como "guetos femininos", de ambientes limpos e com funçóes de maior destreza em detrimento de força (HIRATA, 2015, p. 6). Outro ponto é a disparidade entre os cargos de nível superior. Essa distribuiçáo desigual entre os cargos de um mesmo "nível de escolaridade" mantém a distinção comum entre funções segmentadas e hierárquicas, como é o caso das ocupaçôes de engenharia, encaradas pelas pesquisas de gênero como mais "masculinas"; entretanto, chama a atenção o número relativamente maior de mulheres no cargo de gerência, que denota 
certa autoridade e possibilidade criativa comumente direcionada aos cargos ocupados por homens (HIRATA, 2015).

Para além dos dados aqui apresentados, um estudo mais aprofundado acerca das atividades desempenhadas em cada função é necessário para compreender essas características. Contudo, os dados apresentados nos gráficos geram questóes acerca dessa convergência com os estudos de Hirata (2015), segundo os quais a divisão sexual do trabalho segue uma lógica de atribuições por papéis historicamente considerados femininos ou masculinos.

Os Gráficos 6 e 5 correspondem às ocupaçóes com maior quantidade de vínculos em 2017 controladas pela escolaridade. A primeira mudança perceptível na última década diz respeito às profissóes que mais concentram trabalhadores, tanto homens quanto mulheres, o que pode indicar tanto alteraçóes operacionais (com novos arranjos nas fábricas), quanto institucionais (com alteração do nome dessas profissôes nas carteiras de trabalho).

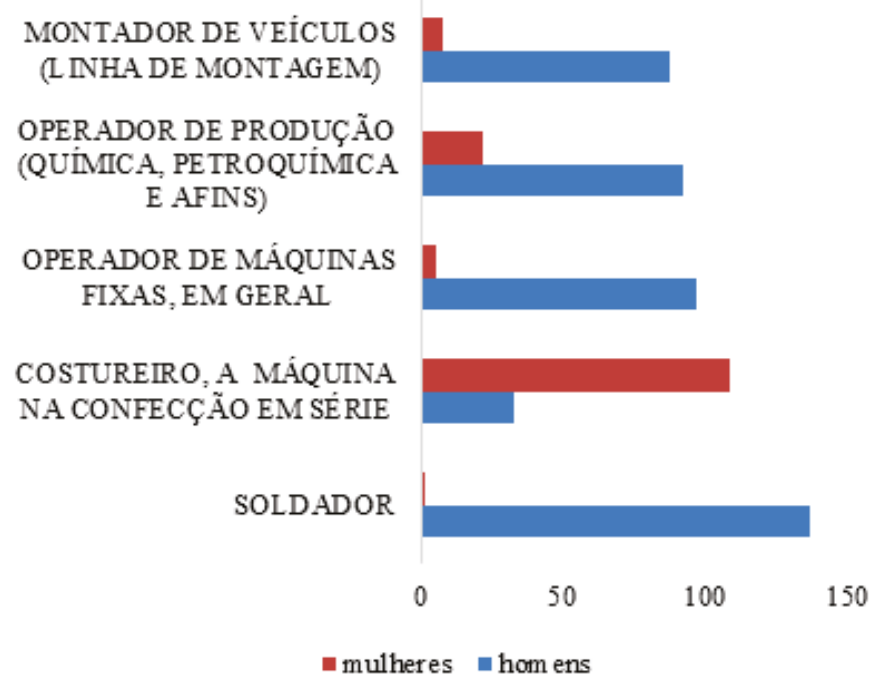

Gráfico 5 - Cinco profissões com maior quantidade de vínculos com ensino médio em 2017

Fonte: Elaborado pelos autores (2021). 


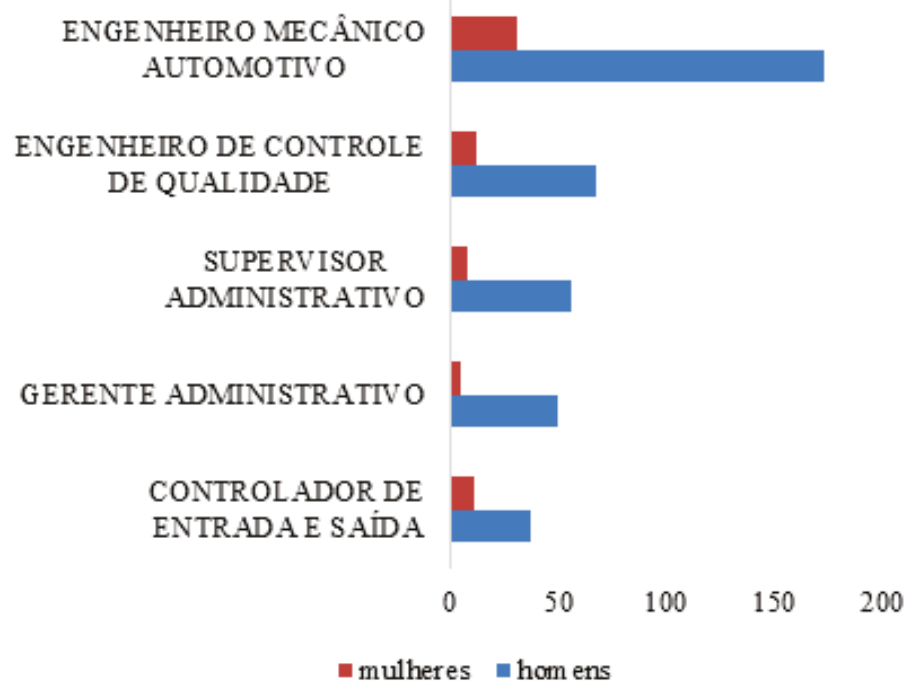

Gráfico 6 - Cinco profissões com maior quantidade de vínculos com ensino superior em 2017

Fonte: Elaborado pelos autores (2021).

A lógica na interpretação das distribuiçóes por gênero nas profissões segue o que analisamos para a década anterior, com uma atenção especial à ocupação de "costureiro ou costureira" e "soldador", que são profissóes emblemáticas na separação recorrente dos cargos tidos como femininos ou masculinos. A função de costura provavelmente diz respeito aos bancos e estofados dos automóveis produzidos nas plantas da região, e é a única dentre as mais ocupadas a ter maioria de trabalhadoras, possivelmente por se tratar de uma posição dentro da linha de montagem associada a qualidades como destreza, minúcia, características entendidas como femininas (RIZEK; LEITE, 1998). A profissão de soldador possuía apenas uma trabalhadora mulher (1,38\%) em contraste com 137 (98,62\%) homens, em 2017, reforçando o número que já era muito pequeno na década anterior - 23 (4,55\%) mulheres; 482 (95,44\%) homens. 


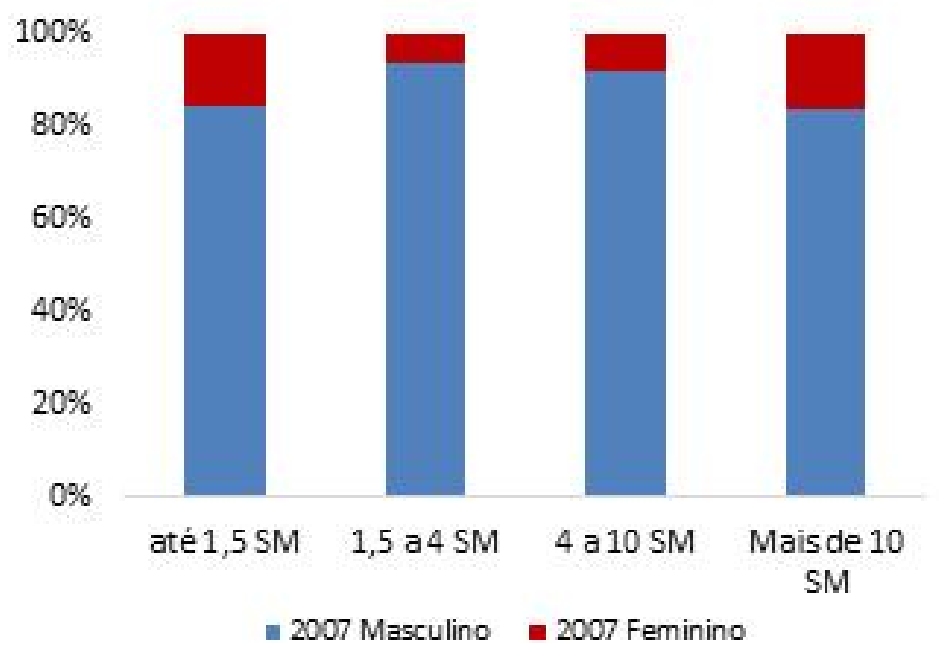

Gráfico 7 - Gênero x Renda em SM em 2007 Fonte: RAIS (2007, 2017).

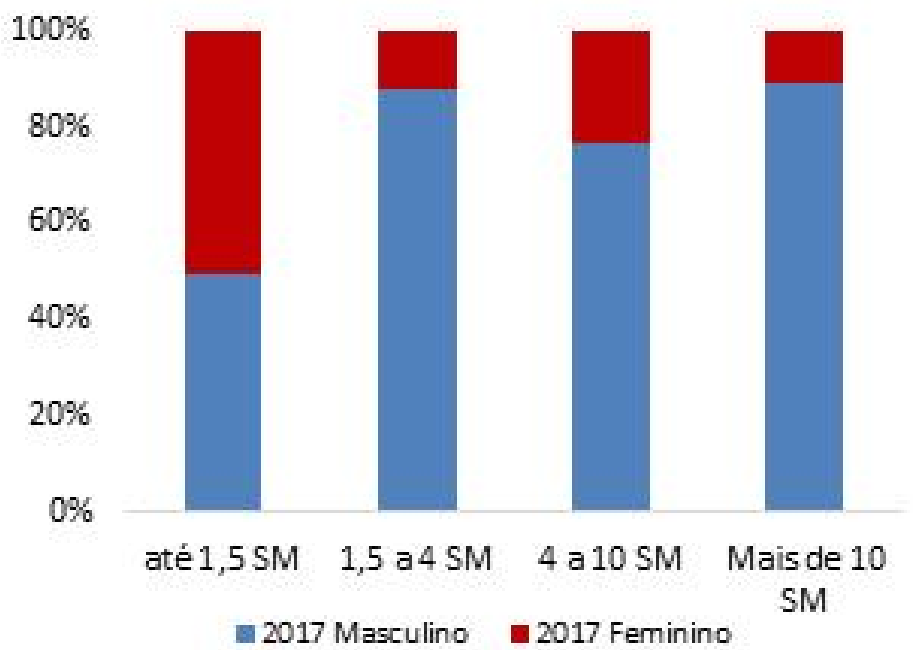

Gráfico 8 - Gênero x Renda em SM em 2017 
Em relação à renda, a participação feminina aumentou em todas as faixas salariais de 2007 para 2017, conforme ilustram os Gráficos 7 e 8 . Os dados apresentam que, entre os trabalhadores no nível mais baixo de renda, até 1,5 salários mínimos, 60\% são mulheres em 2017. Por outro lado, em todas as faixas superiores de remuneração, os homens são proporcionalmente maiores, o que indica que as trabalhadoras mulheres seguem ganhando menos, conforme o princípio hierárquico apresentado por $\mathrm{Hi}$ rata e Kergoat (2007).

Em 2017, a porcentagem levemente maior de mulheres na terceira faixa (entre 4 e 10 salários mínimos) em comparação com a segunda (entre 1,5 e 4 salários mínimos) e quarta (mais que 10 salários mínimos) faixas pode ser explicada pela ocupação de cargos administrativos que costumam ter remuneraçóes maiores que os cargos das linhas de montagem e menores que os cargos de diretoria, gestão ou liderança. Esses são cargos controlados por níveis de escolaridade e alto valor social.

Tabela 2 - Diferença salarial média (média salarial masculina - média salarial feminina) em reais por gênero em 2007 e 2017 para ocupações com ensino médio completo

\begin{tabular}{lccc}
\hline \multicolumn{1}{c}{ Ocupação } & $\mathbf{2 0 0 7}$ & $\mathbf{2 0 1 7}$ \\
\hline Assistente Administrativo & 2.187 & 79 \\
\hline Auxiliar de Escritório, em Geral & 3.302 & 507 \\
\hline Controlador de Entrada e Saída & 1.546 & -724 \\
\hline Inspetor de Qualidade & 512 & 645 \\
\hline Montador de Veículos (Linha de Montagem) & 231 & 230 \\
\hline Soldador & 64 & 565 \\
\hline Técnico em Segurança no Trabalho & 695 & 1.998 \\
\hline
\end{tabular}

Fonte: RAIS (2007, 2017).

As Tabelas 2 e 3 apresentam a diferença salarial em reais, por gênero, dos trabalhadores com ensino médio completo e ensino superior completo nos anos de 2007 e 2017. Novamente, foram usados somente dois níveis de instrução, pois são aqueles que possuem maior quantidade de vínculos. O objetivo deste cruzamento foi identificar em quais ocupaçóes esses 
trabalhadores estão distribuídos e avaliar as discrepâncias salariais entre profissionais que desempenham funções semelhantes. Os cargos elencados são os que possuíam trabalhadores de ambos os sexos nos dois anos escolhidos para comparação. A diferença foi calculada pela subtração da renda média masculina pela feminina. Desse modo, para os casos em que as mulheres recebiam a mais que os homens, os valores indicados na tabela aparecem em negativo. É importante salientar que as variaçóes salariais entre firmas náo estão contempladas na análise nesse primeiro momento, e podem indicar fatores de variação entre os salários, sendo necessária essa análise em trabalhos futuros e mais aprofundados sobre o tema. O que nos cabe neste trabalho é uma comparação entre a média de todas as montadoras aqui abordadas.

Nos cargos cujo grau de escolaridade era ensino médio completo conforme descrito na Tabela 2 , o único caso no qual a remuneração salarial feminina excede a masculina é no cargo de "controlador de entrada e saída" no ano de 2017. Neste caso, as mulheres detêm proporcionalmente maior tempo de empresa do que os homens de mesma função e escolaridade, ocupando o cargo em questáo (RAIS, 2017); isso pode justificar a diferença salarial entre os gêneros. Em 2017, ocupavam este cargo: dois homens contratados há menos de um ano, com média salarial de R \$ 3.828,00; um homem contratado entre um e três anos, com média salarial de $\mathrm{R} \$ 1.353,00$; dois homens contratados entre três e cinco anos, com média salarial de $\mathrm{R} \$ 4.017,00$; e três homens contratados há mais de cinco anos, com média salarial de $\mathrm{R} \$ 3.143,00$; contra uma mulher contratada entre três e cinco anos, com média salarial de $\mathrm{R} \$ 2.365,00$; e uma mulher contratada há mais de cinco anos, com média salarial de $\mathrm{R} \$$ 5.700,00 (RAIS, 2017).

Em todos os outros cargos elencados, os homens recebiam em média salários maiores que as mulheres da mesma função. Chama a atenção a diferença de remuneração para as profissōes de "assistente administrativo", "auxiliar de escritório, em geral" e "controlador de entrada e saída" em 2007; e de "técnico em segurança no trabalho" em 2017. Nestes casos, os homens recebiam em média mais de $\mathrm{R} \$ 1.000,00$ do que as mulheres com mesma escolaridade, desempenhando a mesma função. É importante mensurar que, mesmo dentro da indústria automotiva, as funçóes 
administrativas são comumente mais ocupadas por mulheres; entretanto, isso não significa que elas se tornem maioria, assumam posição de destaque na divisão de funçóes da equipe, ou seja, recebam remuneração salarial semelhante a suas contrapartes masculinas (RAIS, 2007, 2017).

A ocupação "montador de veículos" possui mais homens empregados do que mulheres, conforme descrito nos Gráficos 5 e 3; contudo, a diferença salarial entre os trabalhadores não é tão ampla. Esta se manteve praticamente a mesma entre os dez anos, variando de $\mathrm{R} \$ 231,00 \mathrm{em} 2007$, para $\mathrm{R} \$ 230,00$ em 2017. Trata-se de um dado que contradiz a literatura, uma vez que esse trabalho compóe a linha de montagem e os estudos costumam indicar que, nessas profissóes, além haver mais homens trabalhando, a discrepância entre os salários de homens e mulheres tende a ser elevada (LOBO, 1991; LAPA, 2018).

De acordo com a Tabela 3, entre os cargos de ensino superior completo, as diferenças são mais significativas, chegando a mais de $\mathrm{R} \$ 9.000,00$ em 2017, nas ocupações "auditor (contador e afins)" e "gerente de produtos e operaçóes". No primeiro cargo citado, em 2007 havia 28 homens empregados com salário médio de $\mathrm{R} \$ 2.725,52$ e duas mulheres com o salário médio de $\mathrm{R} \$ 2.051,07$. Já em 2017, o número de homens caiu para quatro, mas sua média salarial saltou para $\mathrm{R} \$ 12.722,05$, com salários que variavam de $\mathrm{R} \$ 6.466,97$ a $\mathrm{R} \$ 22.475,73$. O número de mulheres, por sua vez, manteve-se o mesmo neste intervalo, e sua média salarial subiu para R\$ 3.202,00. Na ocupação "gerente de produção e operação", em 2017 , havia 57 trabalhadores homens e quatro trabalhadoras mulheres. Enquanto as mulheres com cargos de "gerentes de produção e operaçóes" com ensino superior contratadas entre um e três anos recebem remuneração média de R\$ 10.262,00; para os homens de mesma escolaridade e tempo de serviço, este valor sobe para $\mathrm{R} \$ 34.191,19$. Entre os profissionais da área com mais tempo de serviço, a diferença salarial entre homens e mulheres persiste, ainda que de forma menos intensa. Enquanto os homens contratados há mais de cinco anos recebiam média salarial de $\mathrm{R} \$ 17.861,96$, as mulheres em posição semelhante recebiam em média R\$ 14.67849 (RAIS, 2017). 
Tabela 3 - Diferença salarial média (média salarial masculina - média salarial feminina) em reais por gênero em 2007 e 2017 para ocupações com ensino superior completo

\begin{tabular}{lcc}
\hline \multicolumn{1}{c}{ Ocupação } & $\mathbf{2 0 0 7}$ & $\mathbf{2 0 1 7}$ \\
\hline Administrador & 474 & -607 \\
\hline Analista de Desenvolvimento de Sistemas & -4.247 & -724 \\
\hline Analista de Exportação e Importação & 779 & 154 \\
\hline Analista de Recursos Humanos & 3.069 & 695 \\
\hline Assistente Administrativo & 57 & 256 \\
\hline Auditor (Contadores e Afins) & 1.096 & 9.519 \\
\hline Comprador & 4.032 & 369 \\
\hline Contador & 2.285 & 4.057 \\
\hline Controlador de Entrada e Saída & -492 & 374 \\
\hline Engenheiro de Controle de Qualidade & 2.111 & 1.562 \\
\hline Engenheiro de Produção & 1.533 & 1.243 \\
\hline Gerente de Produção e Operações & 2.907 & 9.071 \\
\hline Gerente de Recursos Humanos & 3.053 & -6.842 \\
\hline Inspetor de Qualidade & -49 & 846 \\
\hline Montador de Veículos (Linha de Montagem) & 389 & -34 \\
\hline Supervisor Administrativo & 207 & 3.441 \\
\hline Técnico de Planejamento de Produção & 2.815 & 334 \\
\hline
\end{tabular}

Fonte: RAIS (2007, 2017).

Tendo em vista o avanço no grau de escolaridade, esses dados se encaixam com os argumentos apresentados pela literatura (HIRATA, 2015; LAPA, 2018) em que o fenômeno do teto de vidro limita às ocupaçóes de cargos caracterizados socialmente "femininos", como os cargos de recursos humanos, um maior progresso de mulheres.

O módulo da diferença salarial entre homens e mulheres cresceu ao longo destes dez anos em sete dos 17 cargos listados na Tabela 3 - são eles: "administrador", "assistente administrativo", "auditor (contadores e afins)", "contador", "gerente de produção e operaçóes", "inspetor de qualidade", "supervisor administrativo". Nas funçôes "administrador", "gerente 
de recursos humanos" e "montador de veículos (linha de montagem)", em 2017 as mulheres passaram a ter médias salariais superiores às de trabalhadores homens de mesma escolaridade; enquanto o inverso ocorreu para as categorias de "controlador de entrada e saída" e "inspetor de qualidade".

Em média, as mulheres com ensino médio recebiam $\mathrm{R} \$ 1.080,03$ a menos que homens com mesma escolaridade e tempo de serviço em 2007 , diferença que caiu para $\mathrm{R} \$ 602,80 \mathrm{em}$ 2017. Entre os profissionais de ensino superior, este saldo era de R \$ 1.092,04 em 2007 e de R \$ 1.103,26 em 2017, indicando que, para quem tem nível superior, a diferença salarial tende a ser mais elevada conforme descrito por Leone e Baltar (2012). Tais valores foram calculados traçando a média entre a diferença dos salários médios de homens e mulheres de mesma ocupação, escolaridade e tempo de serviço para os anos de 2007 e 2017, separadamente. Portanto, o cálculo foi feito considerando somente os casos em que houvesse trabalhadores dos dois gêneros que compartilhassem, dentro de um mesmo cargo, a mesma escolaridade e o mesmo tempo de serviço.

Esses valores demonstram que, na indústria automotiva do Sul Fluminense, tanto nos anos de 2007, quanto de 2017, os trabalhadores homens recebiam em média remuneraçóes salariais maiores que as mulheres, ainda que ambos ocupassem as mesmas funções, possuíssem escolaridade e tempo de serviço iguais. Se, para os trabalhadores do ensino médio, tal desigualdade salarial demonstrou uma tendência de queda, ao longo da década investigada, entre os profissionais com ensino superior o padrão foi de estagnação. Essa análise desconsidera, contudo, dois padróes possíveis de serem observados através de um exame sobre os dados desagregados, descritos na Tabela 4, que contém um resumo dos casos citados neste artigo. Uma vez que o volume de trabalhadoras mulheres na indústria automotiva é reduzido quando comparado ao total de homens, os números descritos no parágrafo anterior náo expressam a real desigualdade salarial entre homens e mulheres. Em cargos, por exemplo, "técnico em segurança do trabalho" (2007 e 2017), "auditor" (2017), "gerente de recursos humanos" (2007) e "montador de veículos" (2007), dentre os profissionais com ensino superior somente há homens com tempo de serviço acima de três anos, o que puxa a média salarial de cada categoria agregada para cima. 


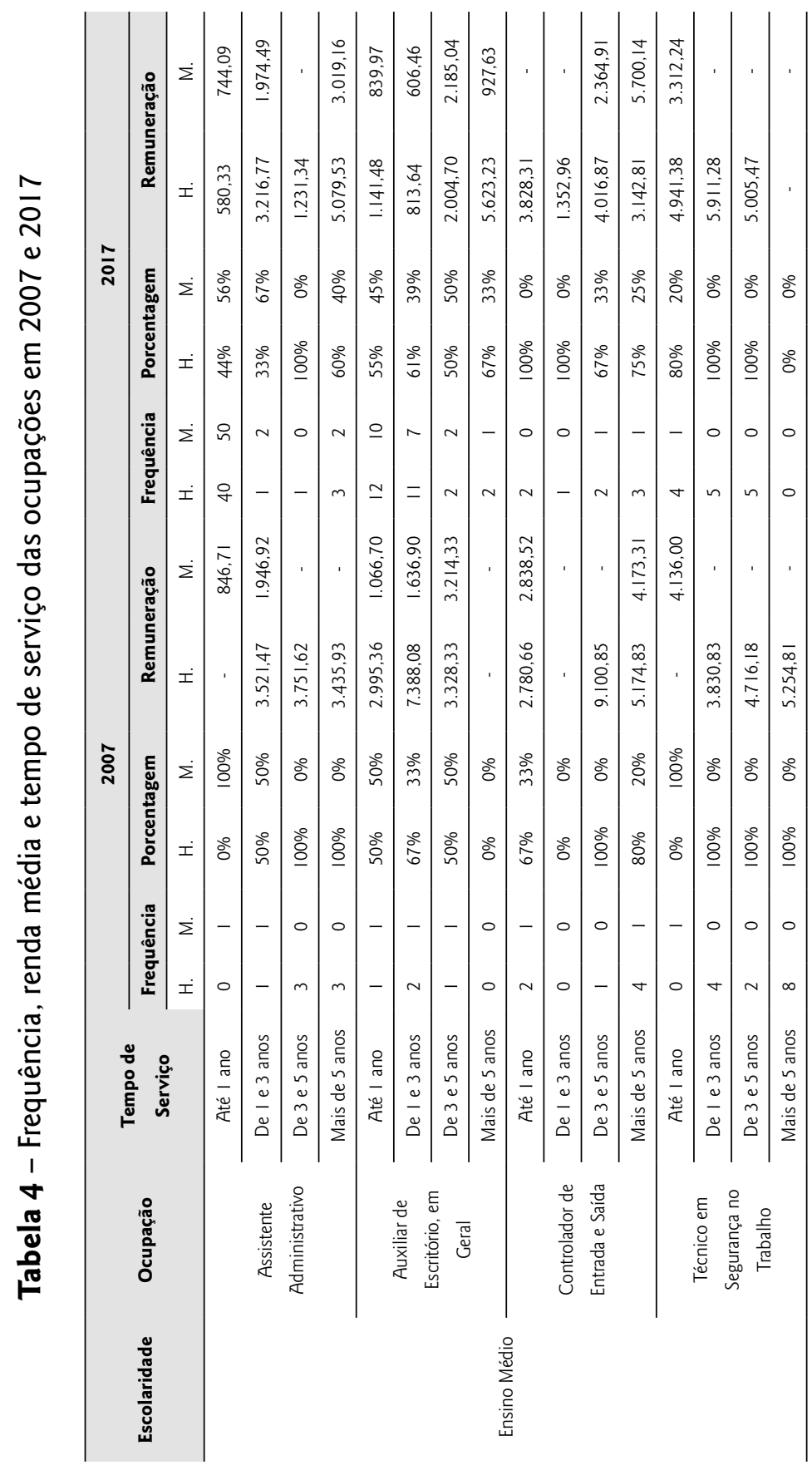




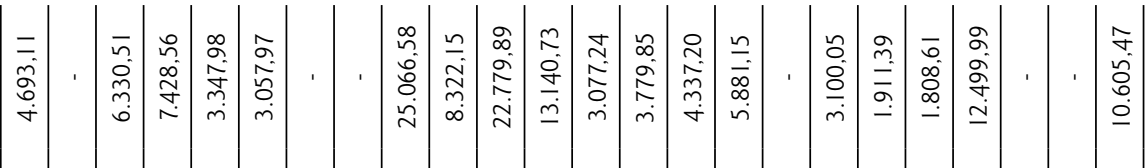

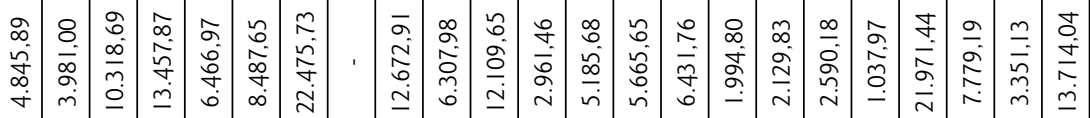
ठิे ठे ठे

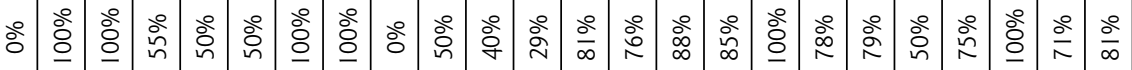

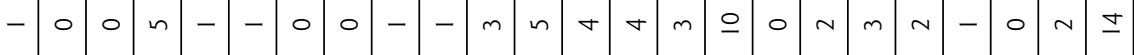

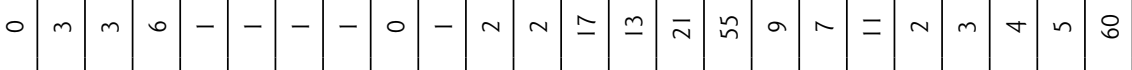

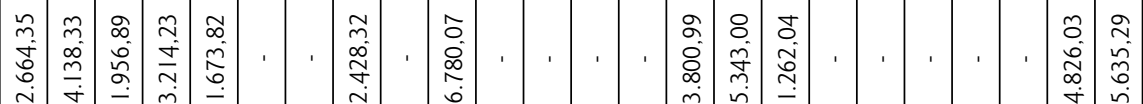

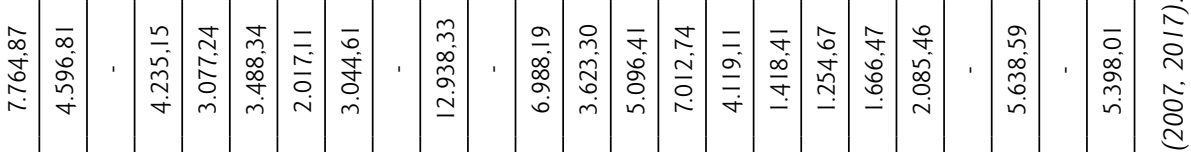

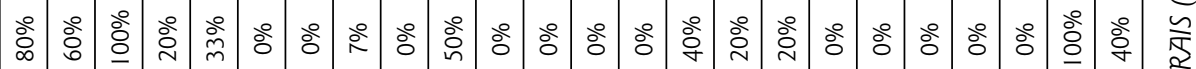
六 守

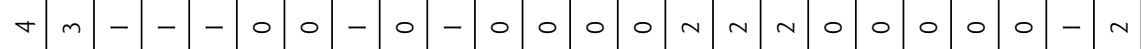

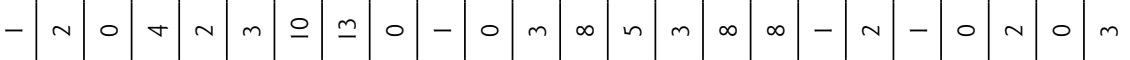

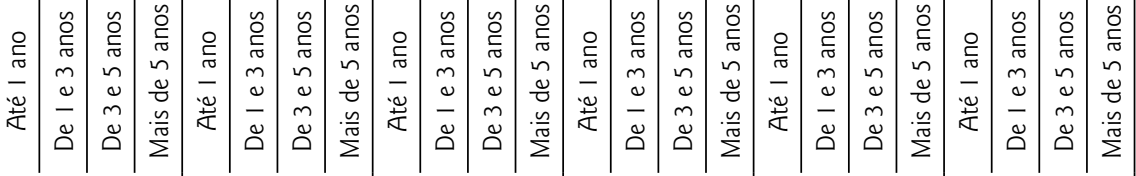

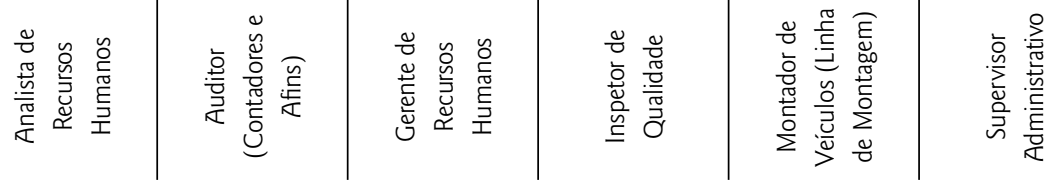

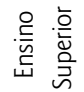


Além disso, a análise dos dados desagregados da Tabela 4 permite notar a existência de casos nos quais um ou dois indivíduos, geralmente do sexo masculino, apresentam remuneraçóes muito acima dos demais trabalhadores que desempenham a mesma função, até mesmo que de seus colegas com maior tempo de serviço. Para as ocupaçôes "auxiliar de escritório em geral" (nível médio, 2007); "analista de recursos humanos", "gerente de recursos humanos" (nível superior, 2007) e "supervisor administrativo" (nível superior, 2017), a diferença salarial média entre homens e mulheres não seria tão elevada se não fosse pela ocorrência deste fenômeno. Isso pode ser um indicativo de que tais indivíduos desempenhem papéis de liderança dentro da equipe, dos quais as mulheres parecem estar sistematicamente excluídas.

A ausência de mulheres em ocupaçóes de liderança também se expressa na posição dos cargos mais elevados, como os postos de diretoria, conforme ilustra a Tabela 5. Em 2007, havia somente dois diretores homens - "diretor administrativo" e "diretor geral da empresa", cujos salários eram, respectivamente, $\mathrm{R} \$ 35.248,09$ e $\mathrm{R} \$ 58.432,94$ - e uma diretora mulher - "diretor de recursos humanos", de salário R\$ 10.090,44. Em 2017, o número de diretores subiu para 29, mas destes somente quatro eram mulheres; enquanto neste ano a remuneração salarial média dos diretores homens variava de $\mathrm{R} \$ 44.281,01$ a $\mathrm{R} \$ 64.176,92$, dentre as mulheres a variação era de $\mathrm{R} \$ 6.914,67$ a $\mathrm{R} \$ 20.076,59$. Esses dados ilustram a outra ponta do fenômeno do teto de vidro apresentado por Hirata (2015) que limita as mulheres às profissóes com características determinadas, estando os cargos de chefia mais atrelados aos valores socialmente vinculados aos homens, como criatividade e controle. $\mathrm{O}$ teto de vidro além de limitar as trabalhadoras a cargos mais baixos hierarquicamente, atribui remuneraçóes maiores aos homens com mesmo grau de escolaridade e mesmas funçóes, mantendo sistematicamente os princípios da separação e hierarquizaçáo.

Observando as tabelas com as profissões, foi possível perceber as diferenças existentes entre as ocupaçóes na indústria automotiva e que as mulheres nesse setor ainda estão longe de alcançar a igualdade, principalmente na linha de montagem e nos cargos de liderança. Ainda se nota que os salários pagos às mulheres, muitas vezes, são menores do que o dos homens. 


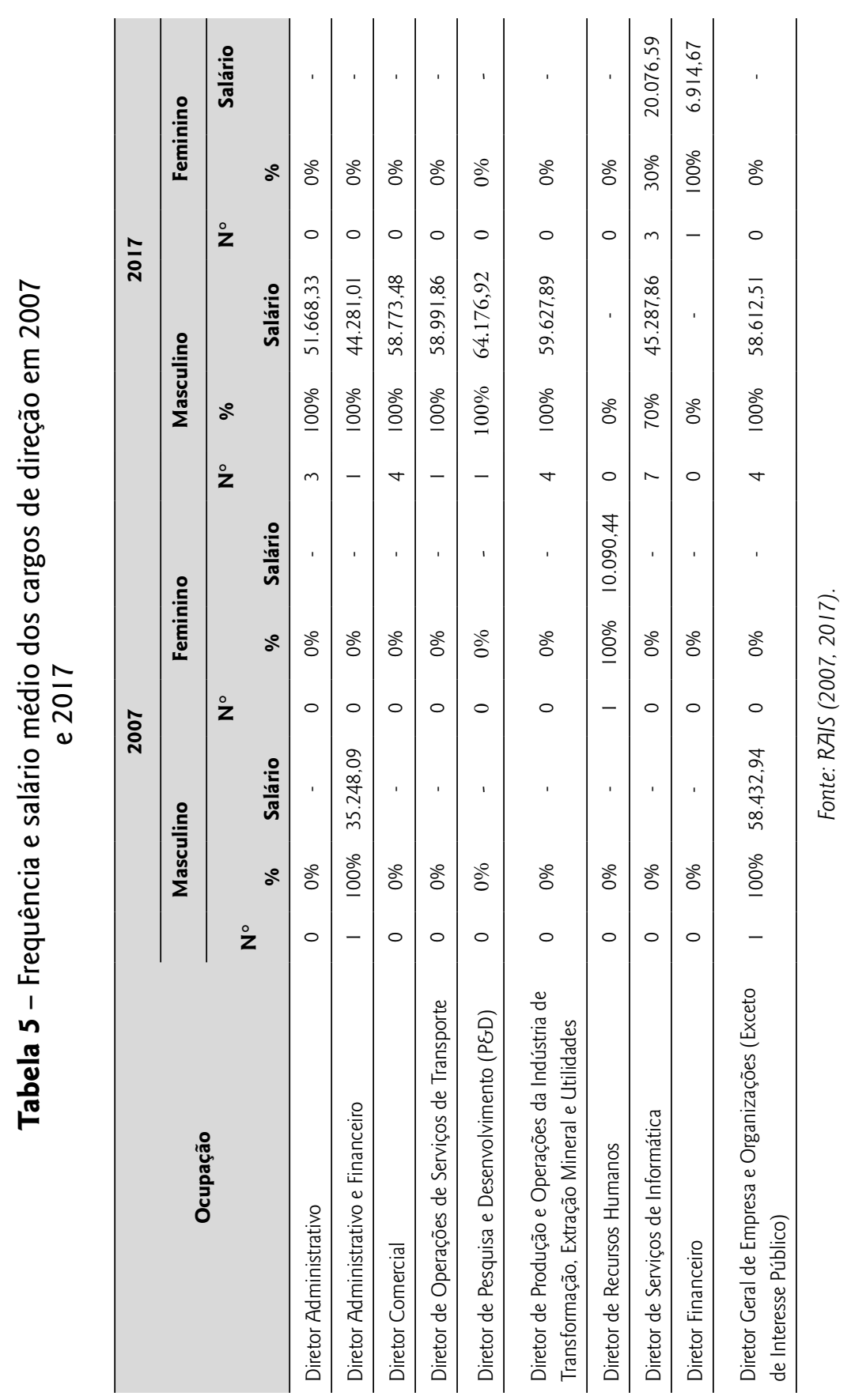




\section{Considerações finais}

Com esta análise dos dados, foi possível lançar luz sobre a discussão relacionada com a persistência da desigualdade entre gênero na indústria automobilística do Sul Fluminense. Embora a PEA dos municípios estudados tenha mais mulheres disponíveis para o mercado de trabalho e porcentagem de mulheres esteja aumentando no setor automotivo, ainda há diferenças acentuadas dentro das fábricas, em relação ao quantitativo de mulheres, aos salários pagos e aos cargos exercidos.

As mulheres ainda estão mais concentradas em posto de trabalho cujas ocupaçóes estão vinculadas às características como cuidado, atenção e delicadeza, tidas como atributos femininos; e, no caso da indústria automotiva, são as funçôes administrativas que são lidas com os atributos citados (RIZEK; LEITE, 1998), mesmo quando possuem nível superior completo. A linha de montagem ainda é um espaço dominado pelos homens. A única exceção notada foi na profissão "montador de veículos", um cargo visto como masculino por ter mais homens desempenhando essa função que mulheres, mas com diferença salarial pequena entre os sexos.

A diferença salarial foi notada para a maioria das ocupaçôes nos dois períodos de tempo, principalmente nos cargos ligados à linha de montagem e com menor escolaridade, conforme já visto na literatura (XAVIER; TOMÁS; CANDIAN, 2009; SILVEIRA; LEÃO, 2017; LEONE; BALTAR, 2012). Isso pode estar relacionado com um machismo latente no momento da contratação, que paga menos às mulheres e estas tendem a aceitar pelos motivos mais diversos, como necessidade de trabalhar por ser arrimo de família ou também porque a renda feminina no domicílio é um complemento no orçamento familiar e o homem desempenhar o papel de provedor (SOARES; IZAKI, 2002). Também pode haver diferenças de salários entre as empresas, algo que não conseguimos controlar em função da limitação dos dados.

Contudo, cabe ressaltar que algumas ocupaçôes apresentaram médias salariais substancialmente maiores das mulheres, por exemplo: "Gerente de Recursos Humanos", "Administrador" e "Analista de Desenvolvimento de Sistemas" em 2017. Estas são profissóes voltadas para o setor administrativo e logístico das empresas e náo apresentaram elevada quantidade de trabalhadores, quando comparados com o universo analisado. 
Em relação a como o tempo de serviço pode influenciar no incremento dos salários, notou-se que, entre os profissionais com ensino médio, há uma tendência de queda na desigualdade salarial conforme o tempo de serviço, mas isto não foi visto entre os trabalhadores com nível superior.

Dentro de suas limitaçóes, a presente pesquisa buscou apresentar um panorama inicial da participação das mulheres no setor automobilístico do Sul Fluminense. Os resultados atingidos contemplam as características apresentadas pela teoria da divisão sexual do trabalho mas não esgotam a análise do tema, fornecendo alguns caminhos que podem ser vislumbrados como desdobramentos deste trabalho, visando a aprofundar o debate das desigualdades de gênero nas montadoras da região: I) Realizar uma comparação entre as empresas existentes nas cidades de Itatiaia, Resende e Porto Real; II) Verificar o tempo médio que as mulheres estão em seus postos de trabalho, pois a não permanência das mulheres que ingressam no mercado de trabalho é um fator relevante na divisão sexual do trabalho. Este fato está relacionado com a dificuldade de as mulheres administrarem seu emprego com a sobrecarga de trabalho não remunerado e as questóes da maternidade; III) Promover a articulaçáo dos dados sobre gênero aqui apresentados com outros fatores relevantes para a análise sistemática das desigualdades no mercado de trabalho, como raça e classe; IV) Através de investigaçóes qualitativas, verificar se o trabalho real exercido por um homem e uma mulher com mesmo cargo é, de fato, similar, uma vez que pode ocorrer uma diferenciaçáo no trabalho real efetuado, como observou Fortino (2009) em seu estudo acerca das fábricas da França.

\section{Referências}

AUTOMOTIVE BUSINESS. Presença feminina no setor automotivo. Pesquisa e debates. 1. ed. São Paulo: Automotive Business, 2018.

BOTELHO, A. Reestruturação produtiva e produção do espaço: o caso da indústria automobilística instalada no Brasil. Revista do Departamento de Geografia, São Paulo, n. 15, p. 55-64, 2002.

DULCI, J. A. Configuraçóes do desenvolvimento em duas novas regióes automobilísticas: sul fluminense e Camaçari (BA). Revista de Ciências Sociais Política \& Trabalho, v. 1, n. 48, p. 75-94, 2018.

FORTINO, S. Mixité au travail, genre et conditions de travail: la construction sociale d'un processus. In: CHAPPERT, F. (org.). Genre et conditions de travail. Mixité, organization du travail, santé et gestion des âges. Lyon: Editions Réseau Anact, 2009. p. 24-43. 
Trabalho e gênero nas indústrias automotivas do Sul Fluminense | Letícia F. Paes, Ana Paula Vasconcelos Gonçalves, Vitor Rodrigues Ferreira

HIRATA, H.; KERGOAT, D. Novas configuraçóes da divisão sexual do trabalho. Cadernos de Pesquisa, v. 37, n. 132, p. 595-609, 2007.

HIRATA, H. Mudanças e permanências nas desigualdades de gênero: divisão sexual do trabalho numa perspectiva comparada. Análise - Fundação Friedrich Ebert Stiftung Brasil, São Paulo, n. 7 , p. 1-24, 2015.

HOFFMANN, R. Desigualdade de gênero: análise adicional. Texto de discussáo: n. 383. Campinas: IE/UNICAMP, 2020.

INSTITUTO BRASILEIRO DE GEOGRAFIA E ESTATÍSTICA (IBGE). Estatísticas do PIB 2010. Rio de Janeiro: IBGE, 2010.

INSTITUTO BRASILEIRO DE GEOGRAFIA E ESTATÍSTICA (IBGE).. Regióes de influência das cidades. Rio de Janeiro: IBGE, 2007.

INSTITUTO BRASILEIRO DE GEOGRAFIA E ESTATÍSTICA (IBGE).. Sinopse do Censo demográfico 2010. Rio de Janeiro: IBGE, 2011.

LAPA, T. S. Desigualdade salarial por sexo: persistências, transformaçôes e desafios. Revista da ABET, v. 15, n. 1, p. 127-138, 2016.

LAPA, T. S. Mulheres metalúrgicas em setores predominantemente masculinos: mudanças sutis e barreiras persistentes. In: ENCONTRO ANUAL DA ANPOCS, 42., 2018, Caxambu. Anais... Caxambu: ANPOCS, 2018. Disponível em: http://anpocs.com/index.php/encontros/papers/42encontro-anual-da-anpocs. Acesso em: 7 set. 2019

LIMA, R. J. da. Açúcar, Cola-Cola e Automóveis: ação político-empresarial na construção de um "município modelo" em Porto Real (RJ). Orientador: José Ricardo Ramalho. 2005. 163 f. Dissertação (Mestrado em Sociologia) - Programa de Pós-Graduação em Sociologia e Antropologia do Instituto de Filosofia e Ciências Sociais da Universidade Federal do Rio de Janeiro, Rio de Janeiro, 2005.

LIMA, R. J. da C.; PAIVA, A. D. de. O Cluster Automotivo Sul Fluminense: experiência de arranjo produtivo ou arranjo institucional?. Desenvolvimento em Questáo, [S. 1.], v. 18, n. 50, p. 10-23, 2020. DOI: 10.21527/2237-6453.2020.50.10-23. Disponível em: https://www.revistas.unijui. edu.br/index.php/desenvolvimentoemquestao/article/view/8152. Acesso em: 8 jun. 2021.

LOBO, E. S. A classe operária tem dois sexos. São Paulo: Editora Brasiliense, 1991.

LEONE, E; BALTAR, P. Um balanço da desigualdade de gênero no mercado de trabalho brasileiro. In: CONGRESO DE LA ASOCIACIÓN LATINOAMERICANA DE POBLACIÓN, 5., 2326 out. 2012, Montevideo. Anais... Montevideo: ALAP2012. Disponível em: http://www.alapop. org/alap/index.php?option=com_content\&view=article\&layout=edit\&id=1571\&Itemid=821. Acesso em:

POSTHUMA, A. C. Mudança de políticas na indústria automobilística brasileira: vestígios da substituição de importações e os impactos da liberalização. In: ABREU, A. R. de P. Produçáo flexível e novas institucionalidades na América Latina. Rio de Janeiro: Editora UFRJ, 2000. p. 128-160. 
RAIS, Relação Anual de Informaçôes Sociais. Ministério do Trabalho e Emprego. Programa de Disseminação das Estatísticas do Trabalho, Brasília, 2007.

RAIS, Relação Anual de Informaçôes Sociais. Ministério do Trabalho e Emprego. Programa de Disseminação das Estatísticas do Trabalho, Brasília, 2017.

RAMALHO, J. R. Novas conjunturas industriais e participação local em estratégias de desenvolvimento. Dados, v. 48, n. 3, p. 491-523, 2005.

RAMALHO, J. R. Indústria e desenvolvimento: efeitos da reinvençáo de um território produtivo no Rio de Janeiro. Revista Pós Ciências Sociais, v. 12, p. 117, 2015.

REIS, L. L. S. W. Proteção ao emprego e renda em tempos de crise: o PPE na Man Latin America. Revista Habitus, Rio de Janeiro, v. 16, n. 1, 2018. Disponível em: https://revistas.ufrj.br/index. php/habitus. Acesso em: 10 jun. 2020.

RESENDE. Municípios assinam protocolo de Consórcio Intermunicipal de Emprego e Renda. Prefeitura Municipal de Resende, 2013. Disponível em: https://resende.rj.gov.br/noticias/municpios-assinam-protocolo-de-cons-rcio-intermunicipal-de-emprego-e-renda. Acesso em: 05 jun. 219.

RIZEK, C.. S.; LEITE, M. de. P. Dimensôes e representaçôes do trabalho fabril feminino. In: ABRAMO, L.; ABREU, A. R. P. Gênero e trabalho na sociologia latino-americana. São Paulo: ALAST/SERT, 1998. p. 281-307.

SILVEIRA, L. S; LEÃO, N. S. Segregação ocupacional e desigualdade de raça e gênero no Brasil, 2000-2010. In: ENCONTRO DA SOCIEDADE BRASILEIRA DE SOCIOLOGIA, 18., 2017, Brasília. Anais... Brasília: SBS, 2017. Disponível em: http://www.adaltech.com.br/anais/ sociologia2017/listaresumos.htm. Acesso em: 05 jun. 2019.

SILVERA, R. Os salários: mantidas as condições desiguais? In: MARUANI, M.; HIRATA, H. (org.). As novas fronteiras da desigualdade. Homens e mulheres no mercado de trabalho. São Paulo: Senac, 2003. p. 151-164.

SOARES, S.; IZAKI, R. S. A participação feminina no mercado de trabalho. Texto para Discussáo do IPEA: n. 293. Rio de Janeiro: IPEA, 2002.

STEIL, A. V. Organizações, gênero e posição hierárquica - compreendendo o fenômeno do teto de vidro. RAUSP Management Journal, São Paulo, v. 32, n. 3, p. 62-69, 1997.

TEIXEIRA, M. O. Desigualdades salariais entre homens e mulheres a partir de uma abordagem de economistas feministas. Gênero - Revista do Núcleo Transdisciplinar de Estudos de Gênero, v. 9, n. 1, p. 32-45, 2008.

XAVIER, F. P., TOMÁS, M. C.; CANDIAN, J. F. Composição ocupacional por gênero, associação a sindicatos e desigualdades de rendimentos do trabalho no Brasil. Revista Econômica, v. 11, n. 1, p. 78-113, 2009. 


\section{Work and gender in the automotive industries of Sul Fluminense}

\section{Abstract}

This paper aims to identify possible gender inequalities relations in the automotive factories of Sul Fluminense - Rio de Janeiro, through the exploratory analysis of data from the Annual List of Social Information (RAIS) of the Ministry of Labour and Employment (MTE). Since 1996, with the arrival of Volkswagen in the municipality of Resende, the state government began to implement policies aimed at attracting other industries, in particular vehicle factories. Over the following years, the municipalities located in Sul Fluminense became a new automotive hub, occupied by a variety of companies that moved the local economy and generated a large volume of jobs. With data from 2007 to 2017, this paper sought to verify how this development influenced the differences portrayed in the literature on gender and work in Brazilian industry.

Keywords: Gender. Inequality. Work. Sul Fluminense. 